\title{
Physical Properties of Tobacco Smoke Particles Produced under Different Conditions*
}

\author{
by Yoshiaki Ishizu, Kazuyo Obta and Hideo Tomita \\ Central Research Institute, The Japan Tobacco \& Salt Public Corporation, \\ Yokobama, Japan
}

\section{SUMMARY}

Small samples of tobacco powder, prepared by grinding the dried tobacco leaves, were heated in a micro-thermobalance in different atmospheres and at different heating rates. The size distribution and the mass concentration of the smoke particles produced were measured simultaneously with a laser particle counter and a piezo balance mass monitor. In addition, the change of weight loss with time was also measured during each experiment. It was found that a larger amount of smoke particles was produced when tobacco was heated in the atmosphere of inert gas and/or at higher heating rates. Furthermore, comparison of measured and calculated size distributions showed that the particle size distribution was governed mainly by coagulation.

\section{ZUSAMMENFASSUNG}

Tabakpulver, das durch Mahlen getrockneter Blätter hergestellt worden war, wurde in kleinen Proben in einer Mikrothermowaage in verschiedenen Atmosphären und mit unterschiedlichen Geschwindigkeiten erhitzt. Größenverteilung und Massekonzentration der sich dabei bildenden Rauchpartikel wurden gleichzeitig unter Einsatz eines Laserpartikelzählers und einer Pie-

\footnotetext{
* Receired: 8th April 1982 - accepted: 22nd March 1983.
}

zowaage gemessen. Darüber hinaus wurde bei jedem Untersuchungsgang auch der Gewichtsverlust mit der Zeit bestimmt. Es zeigte sich, daß sich mehr Rauchpartikel bilden, wenn der Tabak in inerter Atmosphäre und/oder mit hōherer Geschwindigkeit erhitzt wurde. Außerdem zeigte ein Vergleich $z$ wischen berechneter und gemessener Partikelgrōßenverteilung, daß die Partikelgröße entscheidend von der Koagulation bestimmt wird.

\section{RÉSUMÉ}

De petits échantillons de poudre de tabac obtenus à partir de feuilles séchées et moulues ont été chauffés dans une balance microthermique à différentes atmosphères et à des vitesses variables. On mesura simultanément la répartition des tailles et la concentration en masse des particules de fumée ainsi constituées en utilisant un compteur de particules à laser et une balance piézométrique. On mesurz en outre, lors de chaque expérience, la perte de poids en fonction du temps. Il est apparu qu'il se forme davantage de particules de fumée lorsque le tabac est chauffé en atmosphère inerte et/ou à des régimes plus éleves. Par ailleurs, une comparaison entre la distribution des tailles des particules calculée et mesurée fit apparaître que la taille des particules est tégie de façon déterminante par le phénomène de coagulation. 
Figure 1. Schematic dlagram of the experimental apparatus.

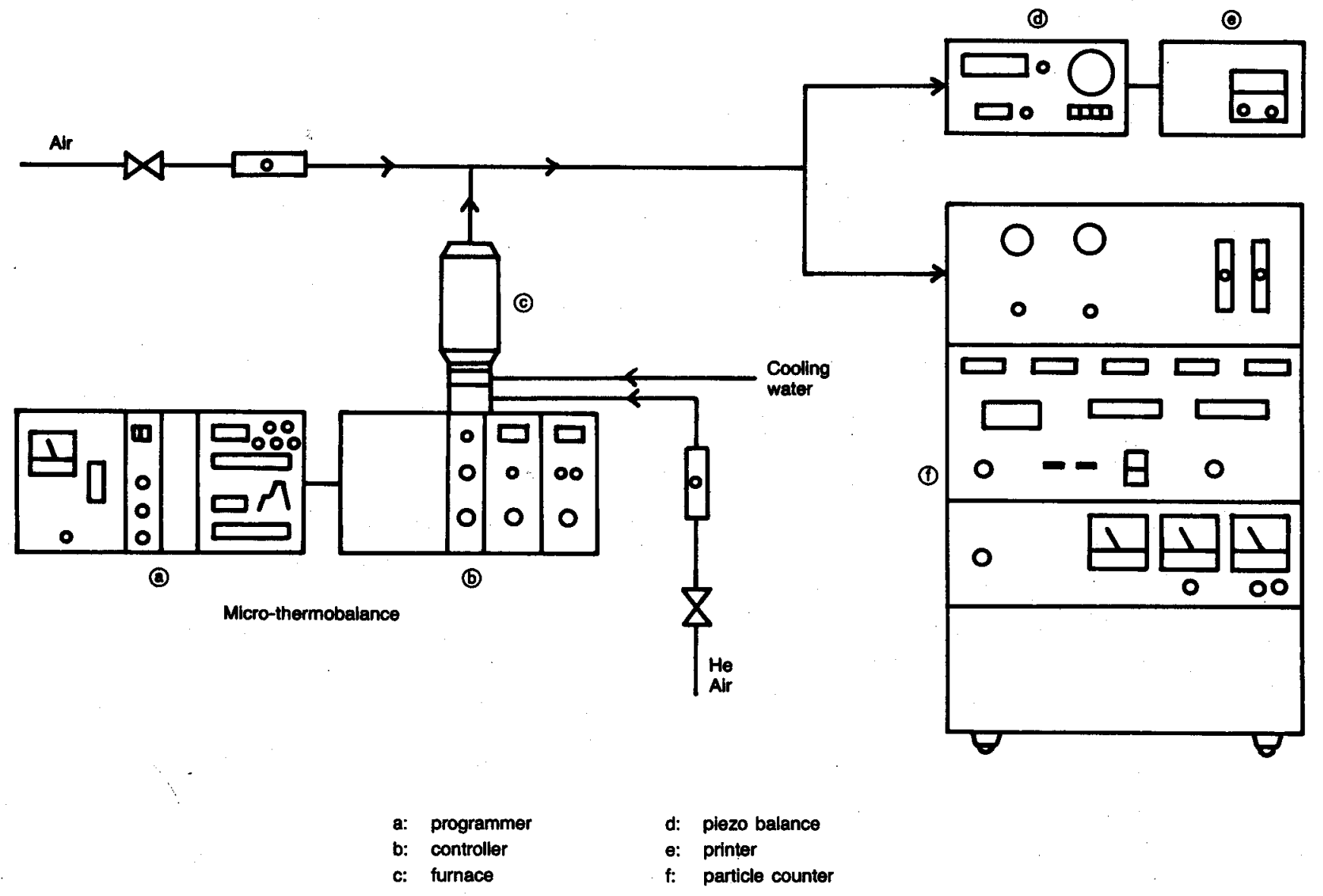

Table 1. Particle size range of the laser particle counter (in dlameter).

\begin{tabular}{c|c|c|c|c|c}
\hline Channel number & 1 & 2 & 3 & 4 & 5 \\
\hline Range $(\mu \mathrm{m})$ & $0.20-0.25$ & $0.25-0.30$ & $0.30-0.40$ & $0.40-0.60$ & $0.60-0.80$ \\
\hline
\end{tabular}


$C_{m}\left(d_{p}{ }^{\prime}\right)$ Cunningham's correction factor

$\mathrm{d}_{\mathrm{p}}^{\prime} \quad$ particle diameter [cm]

$d_{p} \quad$ dimensionless particle diameter $\left(=d_{p}{ }^{\prime} / d_{\mathrm{g}^{\prime}}\right)$

$d_{\mathrm{g}}{ }^{\prime} \quad$ geometric mean diameter at $t=0[\mathrm{~cm}]$

$\mathrm{d}_{\mathrm{g}}{ }^{\prime} \quad$ geometric mean diameter $[\mathrm{cm}]$

$d_{b} \quad$ dimensionless geometric mean diameter $\left(=d_{g} / d_{80}\right)$

$K\left(d_{p}, \delta\right)$ dimensionless coagulation function

$K\left(d_{p}{ }^{\prime}, \delta^{\prime}\right)$ coagulation function for two particles of sizes $d_{p}^{\prime}$ and $\delta^{\prime}\left[\mathrm{cm}^{3} / \mathrm{s}\right]$

$\mathrm{K}_{0} \quad$ coefficient defined by $2 \mathrm{kT} / 3 \mu\left[\mathrm{cm}^{3} / \mathrm{s}\right]$

k Boltzmann's constant $\left(=1.38 \cdot 10^{-16}\right)$ [erg/K]

$n\left(d_{p}, t\right)$ dimensionless number concentration of particles $\left(n^{\prime}\left(d_{q}^{\prime}, t^{\prime}\right) d_{g}{ }^{\prime} / n_{0}{ }^{\prime}\right)$

$n^{\prime}\left(d_{p}{ }^{\prime}, t^{\prime}\right)$ particle size distribution $\left[1 /\left(\mathrm{cm}^{3} \mathrm{~cm}\right)\right]$

$\mathrm{n}_{0}$ (total number concentration of particles at $\mathrm{t}=\mathrm{o}\left[1 / \mathrm{cm}^{3}\right]$

T absolute temperature [K]

$\mathbf{t}^{\prime} \quad$ time [s]

$t$ dimensionless time $\left(=\mathrm{K}_{0} \mathbf{n}_{0}{ }^{\prime} \mathrm{C}_{\mathrm{m}}\left(\mathrm{d}_{\mathrm{g} 0^{\prime}}\right) \mathbf{t}^{\prime}\right)$

$\delta$ dimensionless particle diameter

$\delta^{\prime} \quad$ particle diameter $[\mathrm{cm}]$

$\mu \quad$ viscosity of air $[\mathrm{g} /(\mathrm{cm} \mathrm{s})]$

$\sigma_{\mathrm{g}} \quad$ geometric standard deviation

$\sigma_{g \circ} \quad$ geometric standard deviation at $t=0$

\section{INTRODUCTION}

It goes without saying that tobacco smoke particles are produced in the process of burning. However, because of the complexities of smoke particle production, there are few studies clarifying this phenomenon. On the other hand, many studies have been made on smouldering tobacco, using thermal analysis techniques $(1-4)$, or on the particle size distribution of tobacco smoke $(5-7)$. Thus, as a first step towards establishing a link between burning conditions and tobacco smoke particles, the size distribution and concentration were measured for the smoke particles produced under different environmental and heating conditions, utilizing a thermobalance as smoke preparation equipment.

Further, the change in the particle size distribution is discussed using the coagulation theory.
The experimental apparatus is schematically shown in Figure 1. Tobacco powder, prepared by grinding dried Burley tobacco leaves to pass through an 80 mesh sieve, was loaded in a rapid heating thermobalance equipped with an infra-red image furnace (Shinku Riko Co., Ltd. (TGD-3000)). Smoke particles were produced in an atmosphere of air or helium gas with the heating rate being $10^{\circ} \mathrm{C} / \mathrm{min}$ or $240^{\circ} \mathrm{C} / \mathrm{min}$ in each atmosphere. The flow rate of the gases was set to be $0.11 / \mathrm{min}$. Since the tube before dilution was $1.0 \mathrm{~cm}$ in diameter and $10 \mathrm{~cm}$ in length, the residence time of smoke was approximately 5 seconds. Air flow rate for dilution was $10 \mathrm{l} /$ min and the residence time of smoke after dilution was less than one second. The diluted smoke was then fed simultaneously to a laser particle counter (Hitachi Electronics Engineering Ltd. (TSI-600)) and a piezo balance mass monitor (Nihon Kagaku Kogyo Co., Ltd. (Model 51-1111)) to measure the size distribution and the mass concentration of smoke particles, respectively. Table 1 shows the range of particles measurable by the laser particle counter.

\section{RESULTS}

The results when tobacco powder is heated in air at a heating rate of $10^{\circ} \mathrm{C} / \mathrm{min}$ are shown in Figure 2 . Smoke particles were produced between $200^{\circ} \mathrm{C}$ and $300^{\circ} \mathrm{C}$, which coincided with the first peak of the weight loss rate, corresponding to the pyrolysis of virgin tobacco. However, no smoke particles were produced at the second peak at about $400^{\circ} \mathrm{C}$, which corresponds to the combustion of residual char. The results obtained in helium gas with the same heating rate are presented in Figure 3. In this case, the second peak of weight loss rate did not appear and the production rate of smoke particles became higher. The temperature of smoke particle production was a little higher than that of weight loss. This may be due to the fact that the product at the lower temperature is rich in volatile vapor materials, while that at the higher temperature is not so volatile and is easier to form smoke particles by condensation. The temperature range for smoke production became larger. Figure 4 shows the results for smoke particles obtained in air at a heating rate of $240^{\circ} \mathrm{C} / \mathrm{min}$. Since the heating rate was very high, weight loss rate and production rate of smoke particles were more than ten times as much as those in Figure 2. The size distribution shifted toward larger particles. In addition, Figure 4 shows that the peak temperatures of weight loss rate and smoke production rate were approximately the same as those at which the largest sized particles were formed.

Figure 5 shows the case for helium gas with a heating rate of $240^{\circ} \mathrm{C} / \mathrm{min}$. The production rate of smoke particles became much higher and a larger fraction of the smoke particles was in the larger particle sizes.

Figure 6 shows the relation between the weight of sam- 
Figure 2. Smoke produced in air at a heating rate of $10{ }^{\circ} \mathrm{C} /$ min. Sample weight of tobacco powder was $2.08 \mathrm{mg}$.
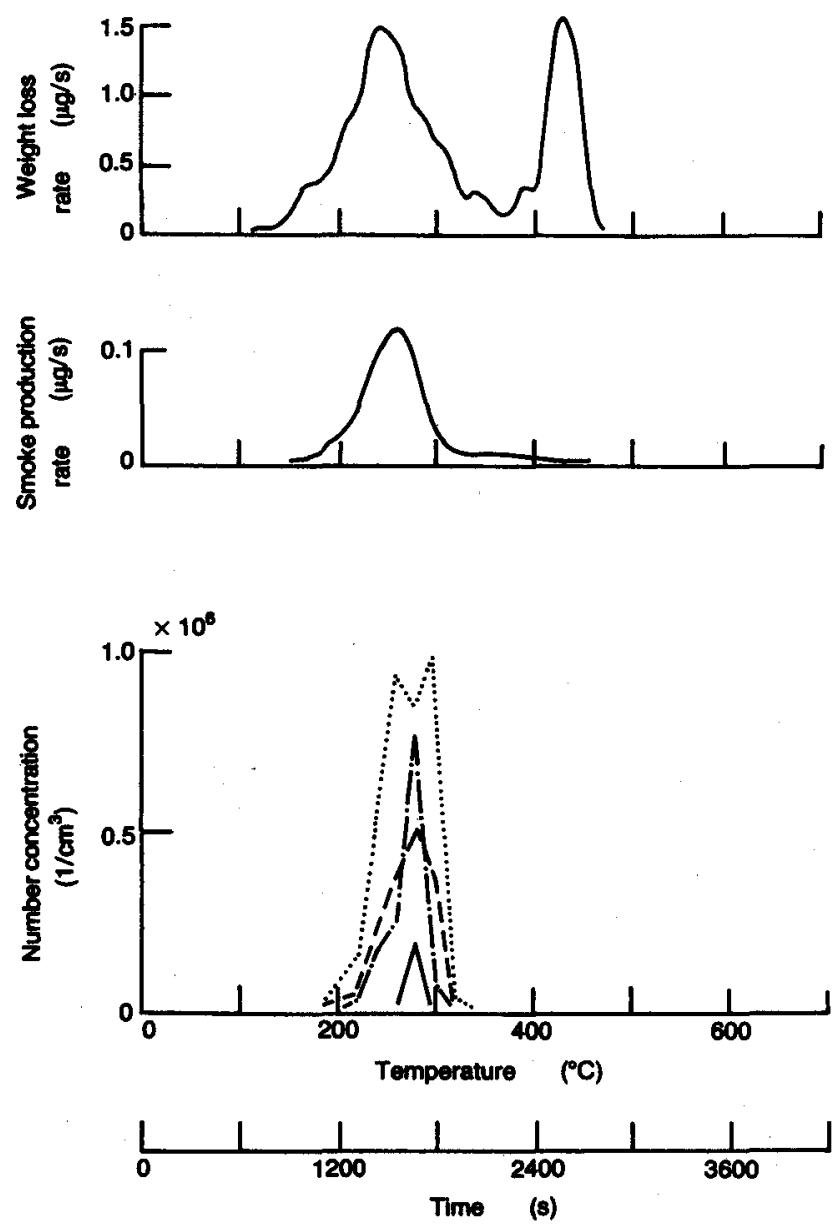

$0.20-0.25 \mu \mathrm{mm}: \cdots$

$0.25-0.30 \mu \mathrm{m}:---$

$0.30-0.40 \mu \mathrm{m}:-\cdot-$

$0.40-0.60 . \mu \mathrm{m}:$
Figure 3. Smoke produced in hellum gas at a heating rate of $10^{\circ} \mathrm{C} / \mathrm{min}$. Sample weight of tobacco powder was $2.03 \mathrm{mg}$.
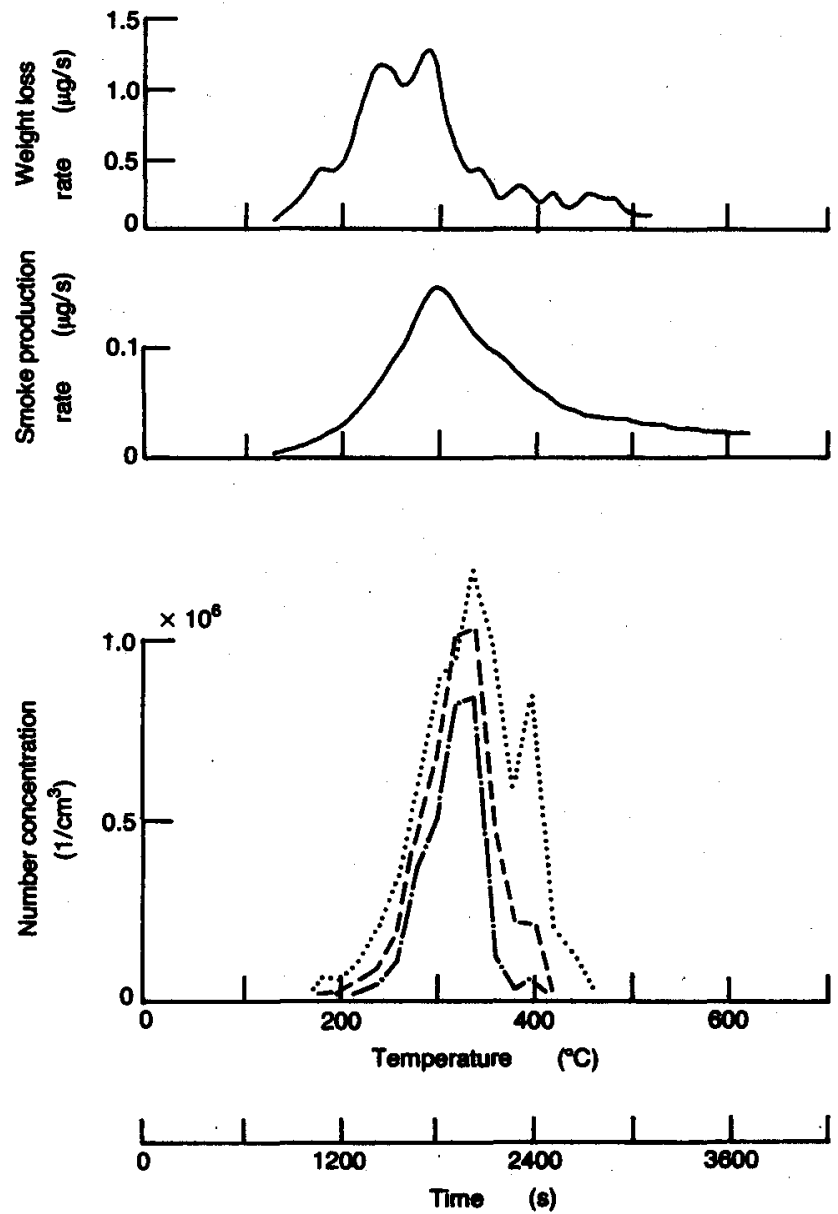

$0.20-0.25$ um: $\cdots \cdots$

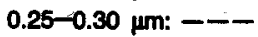

0.30-0.40 $\mathrm{\mu m}:-\cdot-$ 
Figure 4. Smoke produced in air at a heating rate of $240^{\circ} \mathrm{C} / \mathrm{min}$. Sample weight of tobacco powder was $0.75 \mathrm{mg}$.
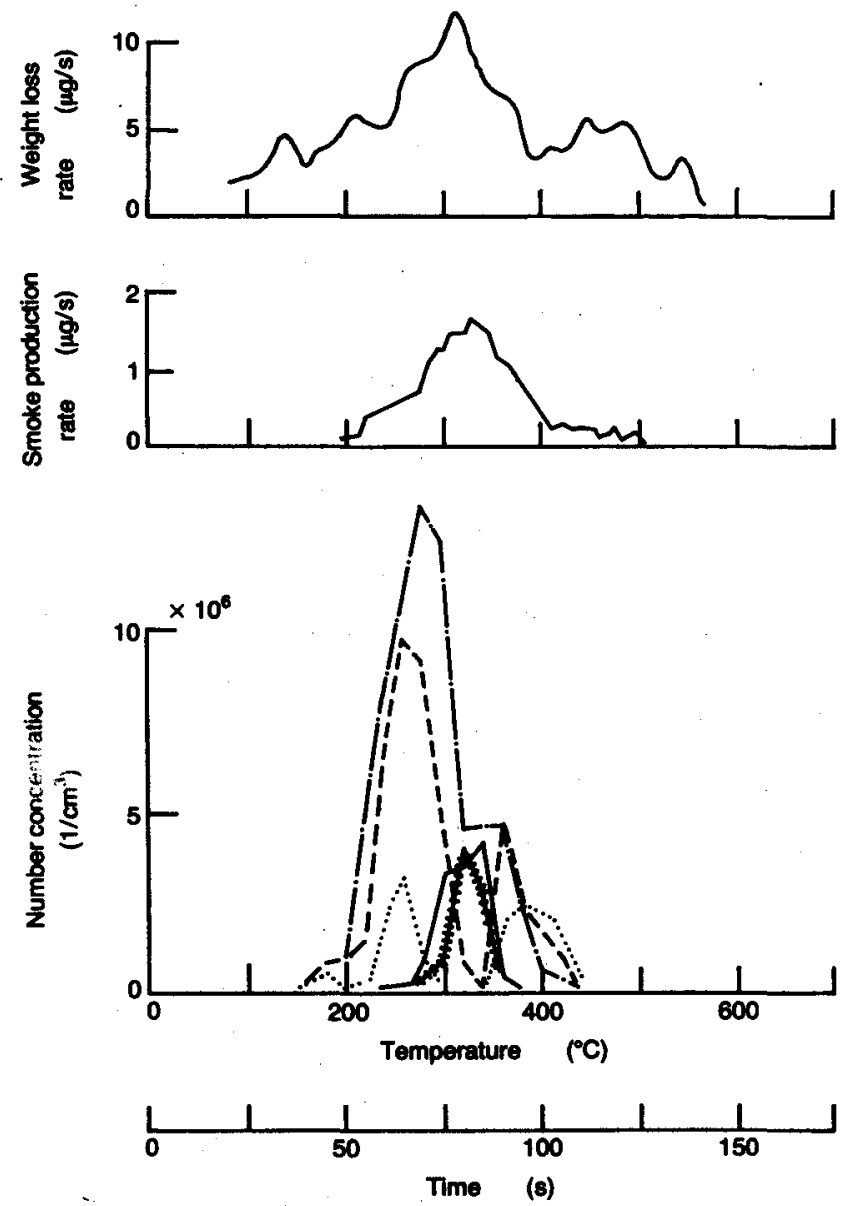

$0.20-0.25 \mu \mathrm{m}: \cdots \cdot$

$0.25-0.30 \mathrm{um}$

$0.30-0.40 \mu \mathrm{m}:-.-$

$0.40-0.60 \mu \mathrm{m}:$

$0.60-0.80 \mu \mathrm{m}: \mathrm{H}+1$
Figure 5. Smoke produced in helium gas at a heating rate of $240^{\circ} \mathrm{C} / \mathrm{mln}$. Sample weight of tobacco powder was $0.72 \mathrm{mg}$.
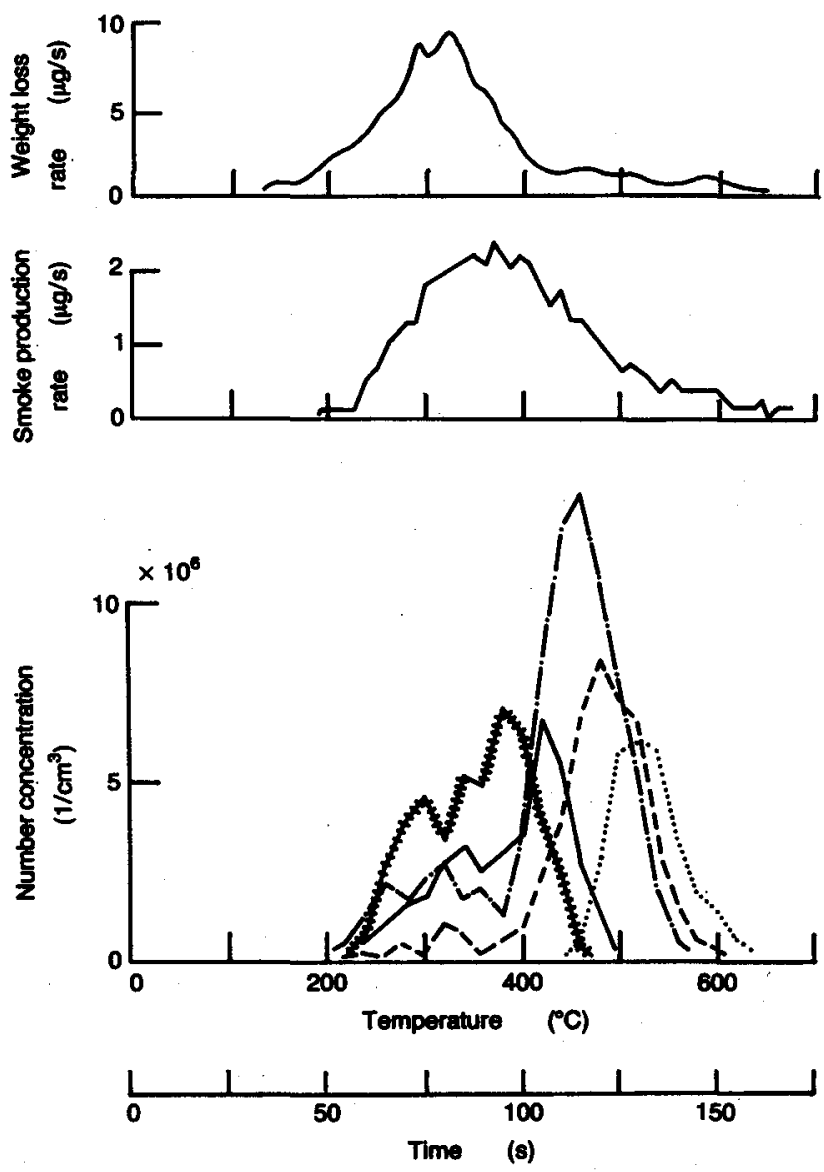

$0.20-0.25 \mu \mathrm{m}: \cdots \cdot$

$0.25-0.30 \mu \mathrm{m}:---$

$0.30-0.40 \mu \mathrm{m}:-\cdot-$

$0.40-0.60 \mu \mathrm{m:}$

$0.60-0.80 \mu \mathrm{m}:$ H世 
Figure 6. The Influence of different heating conditions on the relation between sample weight and smoke wolght. The smoke weight was determined by plezo balance.

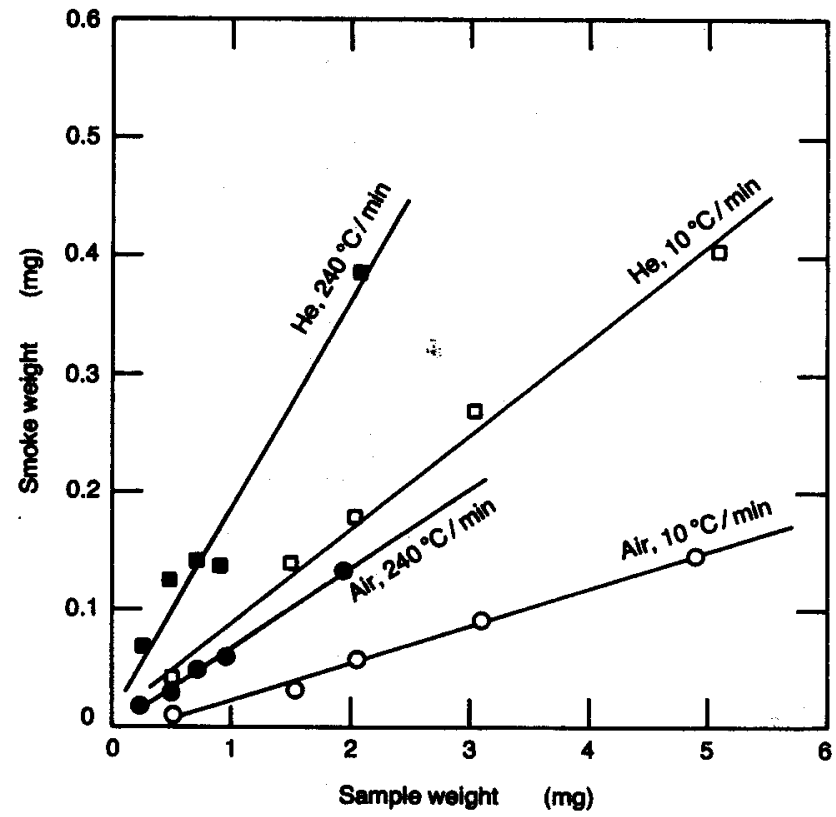

Figure 10. Slze diatributions of smoke particles produced in hellum gas at $240^{\circ} \mathrm{C} / \mathrm{min}$.

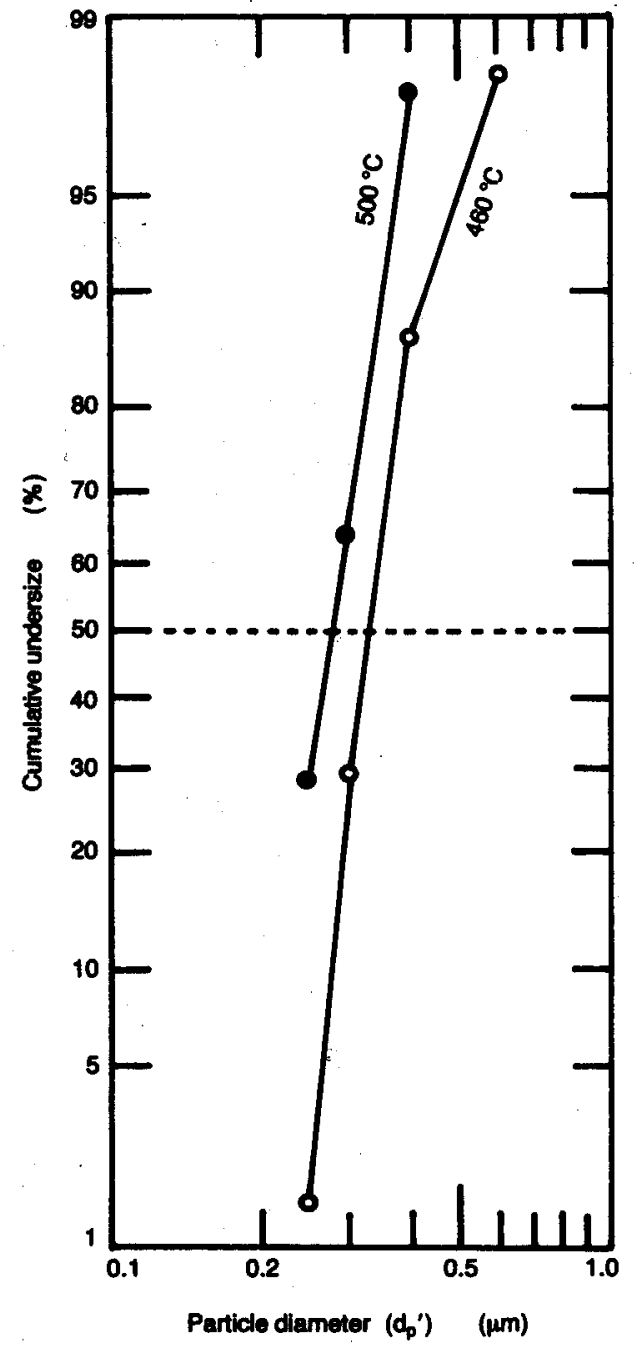

Figure 7. Size distribution of emoke particles produced in alr at $240^{\circ} \mathrm{C} / \mathrm{m} \mathrm{n}$.

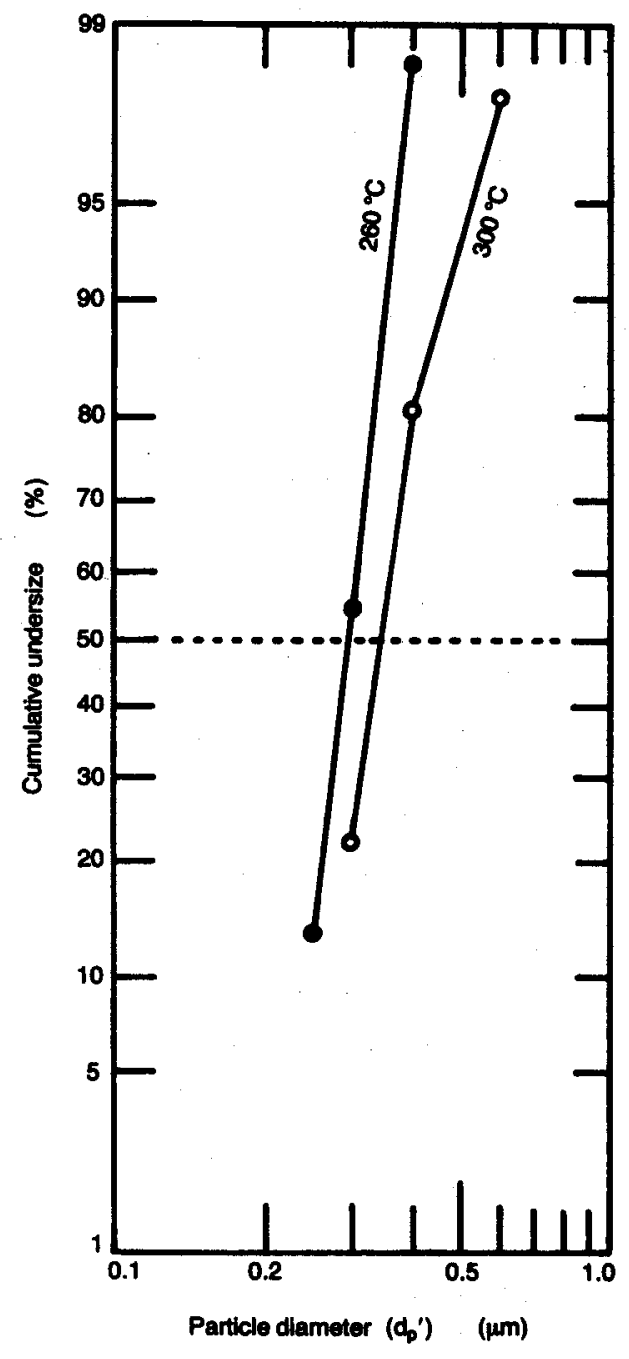

Figure 8. Theoretical chart showing the relation between the ratios of time and the geometric mean diameter.

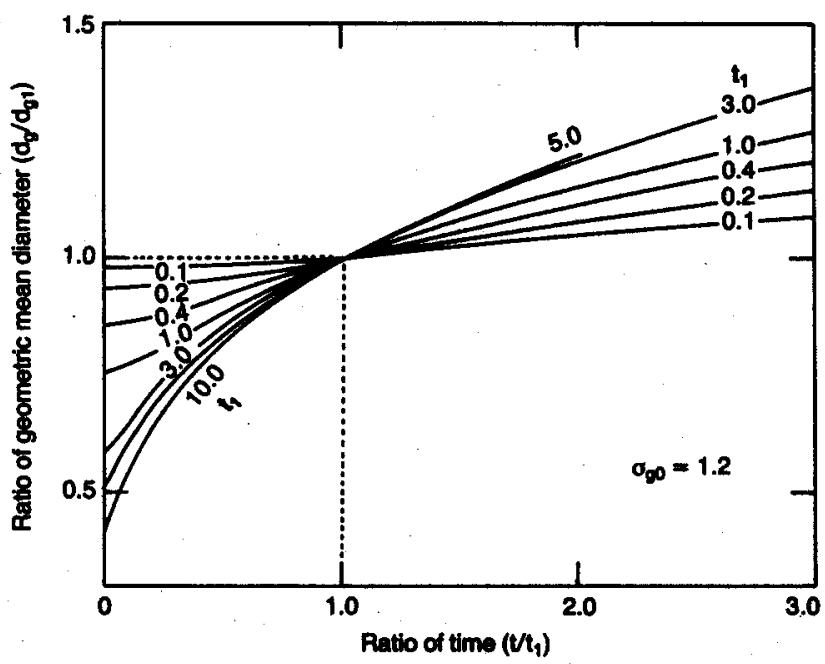


ple tobacco powder and the total weight of smoke particles. It is apparent that the weight of the particles was larger when they were produced in an atmosphere of helium gas, and with a higher heating rate.

\section{DISCUSSION}

It was found that the amount of smoke particles produced and the particle size distribution were strongly dependent on the conditions of smoke production. The effect of the difference in atmosphere can be understood by considering that when tobacco is heated in air, combustion may occur for substances produced during pyrolysis, while no combustion occurs in a helium gas atmosphere.

As mentioned before, when the smoke production rate was high, a larger fraction of the particles was shifted toward greater particle sizes. This fact seems to indicate that coagulation is the dominating factor in determining the size distribution of smoke particles.

It is well known that the change in the particle size distribution by coagulation can be formulized by the population balance equation as follows $(8-10)$ :

$$
\begin{aligned}
& \frac{\partial \mathrm{An}\left(d_{p}, t\right)}{\partial t}= \\
& \quad \int_{\delta=0}^{\delta=d_{p} / \sqrt[3]{2}} K\left(\sqrt[3]{d_{q}^{3}-\delta^{3}}, \delta\right) n\left(\sqrt[3]{d_{p}^{3}-\delta^{3}}, t\right) n(\delta, t) \\
& \quad \times\left(\frac{d_{p}}{\sqrt[3]{d_{p}^{3}-} \delta^{3}}\right)^{2} d \delta-\int_{\delta=0}^{\delta=\infty} K\left(d_{p}, \delta\right) n\left(d_{p}, t\right) n(\delta, t) d \delta
\end{aligned}
$$

where:

$$
\begin{aligned}
& n\left(d_{p}, t\right)=n^{\prime}\left(d_{p}^{\prime}, t^{\prime}\right) d_{g 0} / n_{0}^{\prime} \\
& t \quad=K_{0} n_{0}^{\prime} C_{m}\left(d_{80}\right) t^{\prime} \\
& K\left(d_{\rho}, \delta\right)=K\left(d_{p}^{\prime}, \delta\right) / K_{0} C_{m}\left(d_{80}\right) \\
& d_{p} \quad=d_{p}^{\prime} / d_{80} \\
& K_{0} \quad=2 k T / 3 \mu .
\end{aligned}
$$

All symbols are defined in the Nomenclature section. Usually, this equation is applied to estimate the change in the particle size distribution with time when the initial size distribution is given. In this work, however, measured values were not the change in the particle size with time, but the change with the amount of smoke particles produced. Nevertheless, if the size distribution of smoke particles just after formation is assumed to be constant, the amount of smoke particles produced is proportional to the smoke concentration, $\mathrm{n}_{0}{ }^{\prime}$. Therefore, the amount of smoke produced can be reduced to dimensionless time $t$, because $t$ is expressed as $\mathrm{K}_{0} \mathrm{n}_{0}{ }^{\prime} \mathrm{C}_{\mathrm{m}}\left(\mathrm{d}_{\mathrm{g}}{ }^{\prime}\right) \mathrm{t}^{\prime}$. The problem is then how to estimate the initial size distribution. The residence time $t$ ' can be estimated at about 6 seconds from our experimental set-up, but we do not have sufficient information for other parameters in $t$ except that $d_{80}$ is a certain value. Accordingly, we decided to take the ratio of dimensionless times, $\mathrm{t}_{2} / \mathrm{t}_{1}$, which is $\mathrm{K}_{02} \mathrm{n}_{02}{ }^{\prime} / \mathrm{K}_{01} \mathrm{n}_{01}$. Then, $\mathrm{K}_{02} / \mathrm{K}_{01}$ can be calculated from the temperature and the viscosity of air, and $n_{02}{ }^{\prime} / n_{01}{ }^{\prime}$ can be estimated from the amount of smoke particles. As an example, let us consider the results obtained at $260^{\circ} \mathrm{C}$ and $300^{\circ} \mathrm{C}$ in air with the heating rate of $240^{\circ} \mathrm{C} / \mathrm{min}$. The measured particle size distribution was plotted on a logarithmic normal distribution paper as shown in Figure 7. Since the line was approximately straight, the size distribution of tobacco smoke particles was assumed to be logarithmically normal. From the particle size corresponding to $50 \%$ cumulative undersize, geometric mean diameters were $0.29 \mu \mathrm{m}$ at $260^{\circ} \mathrm{C}$ and $0.34 \mu \mathrm{m}$ at $300^{\circ} \mathrm{C}$. Thus the ratio becomes 1.17. As for dimensionless time, the ratio becomes 2.08 from the calculation described above.

On the other hand, the theoretical chart for $t_{2} / t_{1}$ and $\mathrm{d}_{\mathrm{g}_{2}} / \mathrm{d}_{\mathrm{g} 1}$, which is shown in Figure 8, can be drawn from the numeric calculation. Here, the initial geometric standard deviation $\sigma_{\mathrm{g} 0}$ is taken to be 1.2 from the results shown in Figure 7, assuming that the change of $\sigma_{\mathrm{g}}$ with time is small. Then, placing the above-mentioned values $(2.08,1.17)$ on this chart, $t_{1}$ can be readily obtained as 1.2. This is the dimensionless time for smoke at $260^{\circ} \mathrm{C}$. The initial geometric mean diameter can be estimated by tracing back the curve of $t_{1}=1.2$ toward $t / t_{1}=0$, that is 0.7 times as large as the geometric mean diameter of smoke at $260^{\circ} \mathrm{C}$. The reason why the results obtained at $260^{\circ} \mathrm{C}$ and $300^{\circ} \mathrm{C}$ were chosen to derive the dimensionless time is that at these temperatures, whole size distribution happened to fall in the measurable size of our laser particle counter.

Now, since the relation between dimensionless time and the amount of smoke particles produced at $260^{\circ} \mathrm{C}$ is known from experimental data, dimensionless time at other temperatures can be calculated. Based on these procedures, the particle size distributions from experiment and calculation were compared in Figure 9. The agreement between the measured and calculated size distributions indicate that the coagulation process can explain the observed changes in the particle size distributions. Poor agreement in the case of $220^{\circ} \mathrm{C}$ may be ascribed to the fact that, at this temperature, the nature of the smoke, especially with regard to its chemical composition, may be different, which may complicate the situation.

Similarly, the measured values in helium gas with the heating rate of $240^{\circ} \mathrm{C} / \mathrm{min}$ were also examined. From Figure 10, geometric mean diameters were $0.33 \mu \mathrm{m}$ at $460^{\circ} \mathrm{C}$ and $0.29 \mu \mathrm{m}$ at $500^{\circ} \mathrm{C}$, which gives a ratio of 1.14. The ratio of dimensionless time was 1.63. Accord- 
Flgure 9. Comparison of measured ske distribution with calculated size distribution for smoke particles produced in air at $2400^{\circ} \mathrm{C} / \mathrm{min}$.

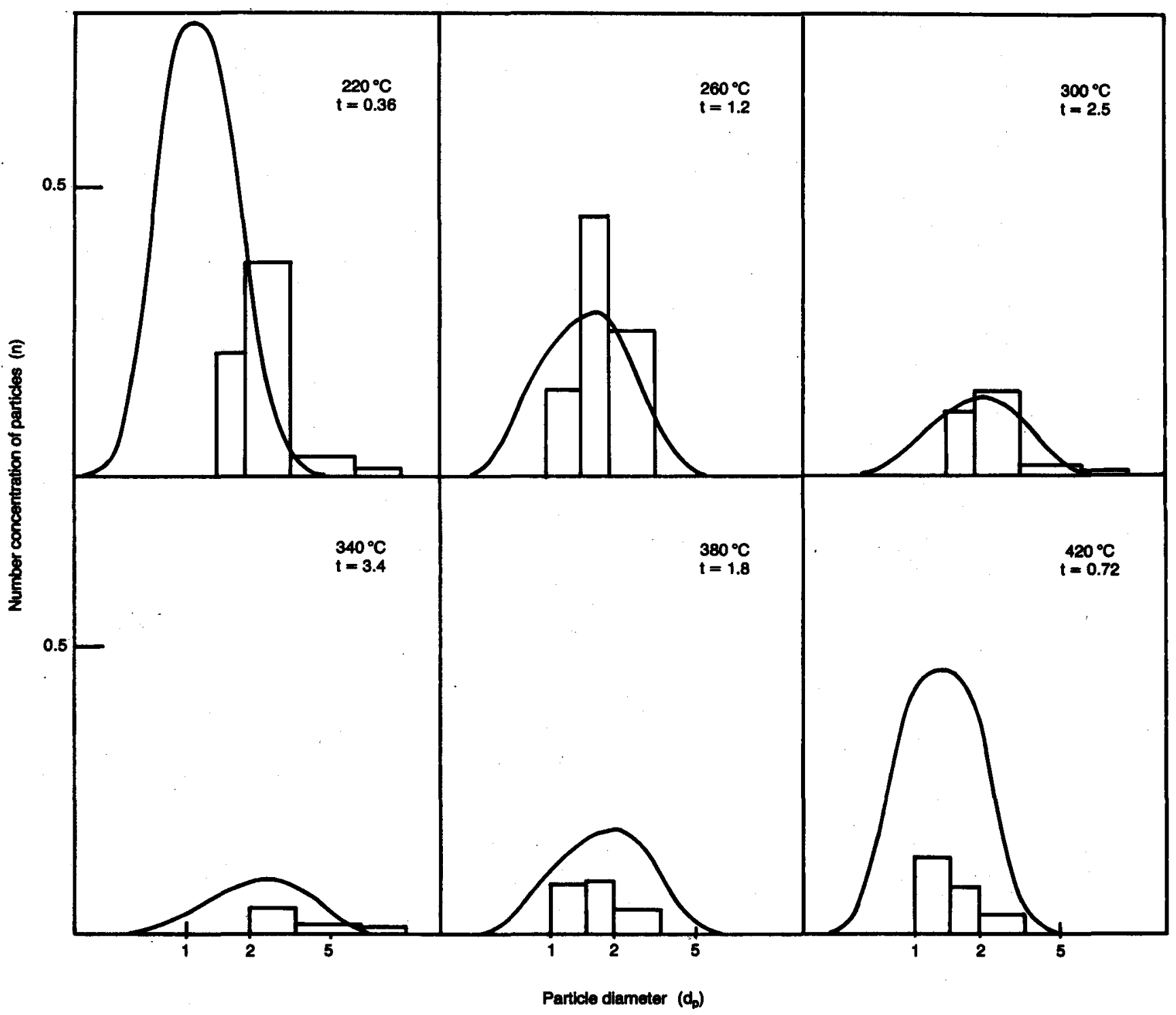


Figure 11. Comparison of measured ske distribution with calculated size distribution for smoke particles produced in hellum gas at $2400^{\circ} \mathrm{C} / \mathrm{min}$.

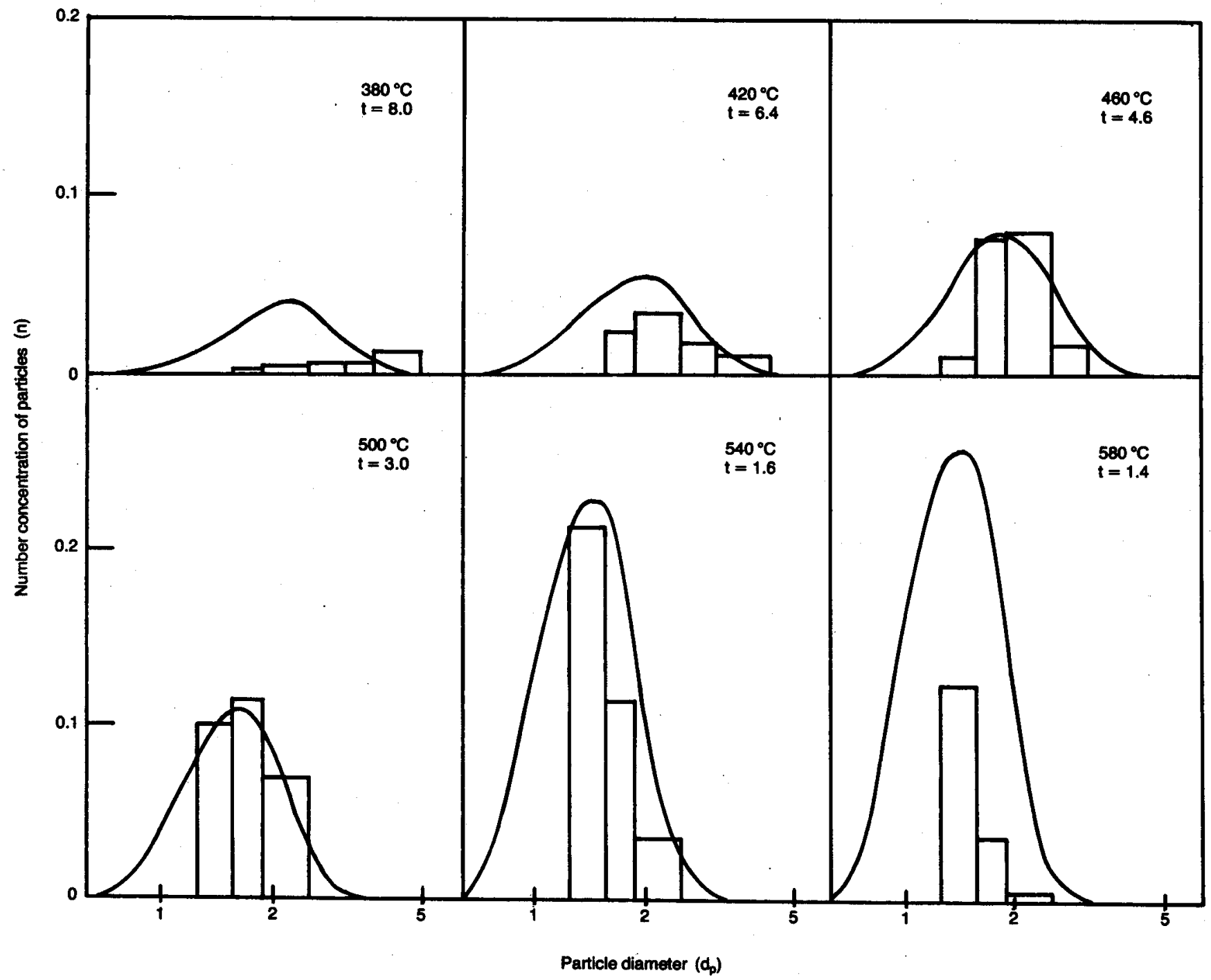

ingly, $t_{1}$ for $500^{\circ} \mathrm{C}$ became 3.0 from the chart presented in Figure 8. The comparison between experimental and calculated results is shown in Figure 11. Agreement was good except at $380^{\circ} \mathrm{C}$.

Although the assumptions contained in this method should be confirmed experimentally, it seems that coagulation is the dominating factor in determining the particle size distribution of tobacco smoke.

\section{REFERENCES}

1. Summerfield, M., T. J. Ohlemiller and H. W. Sandusky: A thermophysical mathematical model of steady-draw smoking and predictions of overall cigarette behavior; Combust. Flame 33 (1978) 263-279.

2. Baker, R. R.: Kinetic mechanism of the thermal decomposition of tobacco; Thermochim. Acta 28 (1979) 45-57.
3. Muramatsu, M., S. Umemura and T. Okada: A mathematical model of evaporation-pyrolysis processes inside a naturally smoldering cigarette; Combust. Flame 36 (1979) 245-262.

4. Baker, R. R.: Product formation mechanisms inside a burning cigarette; Prog. Energy Combust. Sci. 7 (1981) 135-153.

5. Keith, C. H., and J. C. Derrick: Measurement of the particle size distribution and concentration of cigarette smoke by the "Conifuge"; J. Colloid Sci. 15 (1960) 340-356.

6. Okada; T., and K. Matsunuma: Determination of particle size distribution of cigarette smoke by a light-scattering method; J. Colloid Interface Sci. 48 (1974) 461-469.

7. Carter, W. L., and I. Hasegawa: Fixation of tobacco smoke aerosols for size distribution studies; J. Colloid Interface Sci. 53 (1975) 134-141.

8. Fuchs, N. A.: The mechanics of aerosols; Pergamon Press, Oxford, 1964. 
9. Greenfield, M. A., R. L. Koontz and D. F. Hausknecht: Comparison of experiment and theory for the coagulation of aerosols; J. Colloid Interface Sci. 35 (1971) 102-113.

10. Yoshida, T., K. Okuyama, Y. Kousaka and Y. Kida: Changes in particle size distributions of polydisperse aerosols undergoing Brownian coagulation; J. Chem. Eng. Jpn. 8 (1975) 317-322.
Awthors' address:

The Japan Tobacco \& Salt Public Corporation, Central Research Institute,

6-2 Umegaoka, Midori-ku,

Yokohama, Kanagawa, 227, Japan. 